\title{
IMPLEMENTASI PENDEKATAN SAINTIFIK DENGAN AUTHENTIC ASSESSMENT KURIKULUM 2013 DALAM PEMBELAJARAN MATEMATIKA PADA SISWA KELAS VII MTS AL-IHSAN KRIAN
}

\author{
Firda Nuril Yahya \\ Program Studi Pendidikan Matematika FKIP Universitas Islam Malang \\ Email :fanyyow28@gmail.com
}

\begin{abstract}
Abstrak
Penelitian ini bertujuan untuk mendeskripsikan perencanaan, pelaksanaan, penilaian, dan kendala yang ditemui guru beserta upaya guru untuk mengatasinya dalam implementasi pendekatan saintifik dengan authentic assessment kurikulum 2013 pada pembelajaran matematika kelas VII MTs Al-Ihsan Krian. Penelitian ini merupakan penelitian kualitatif deskriptif. Subjek penelitian ini adalah dua guru matematika kelas VII MTs Al-Ihsan. Objek dalam penelitian ini adalah kegiatan yang merupakan bentuk dari implementasi pendekatan saintifik dengan authentic assessment di kelas VII MTs Al-Ihsan Krian. Teknik pengumpulan data menggunakan angket, observasi, wawancara dan dokumentasi. Pengecekan keabsahan data menggunakan teknik triangulasi sumber. Data dianalisis dengan reduksi data, penyajian data dan penarikan kesimpulan. Berdasarkan analisis data dan pembahasan, guru matematika kelas VII MTs Al-Ihsan Krian mengimplementasikan pendekatan saintifik dan authentic assessment pada kegiatan perencanaan, pelaksanaan dan penilaian pembelajaran. Guru juga menemukan beberapa kendala dalam kegiatan perencanaan yang berupa persiapan kurang matang dikarenakan tidak adanya waktu untuk membuat RPP dan sulitnya guru dalam mengembangkan kegiatan pembelajaran. Dalam kegiatan pelaksanaan, guru menemukan kendala yang berupa tidak adanya buku paket siswa dan saran prasarana yang kurang mendukung. Sedangkan dalam kegiatan penilaian pembelajaran kendala yang ditemukan berupa terlalu banyak aspek yang dinilai sehingga guru harus segera merekap nilai agar tidak menumpuk. Guru mempunyai cara tersendiri untuk mengatasi tiap kendala yang dihadapi.
\end{abstract}

Kata Kunci: kurikulum 2013, pendekatan saintifik, authentic assessment

\section{PENDAHULUAN}

Pada abad 21, tantangan di kancah global semakin berat sejalan dengan perkembangan lingkungan yang begitu pesat, seperti teknologi, ilmu pengetahuan, ekonomi dan sosial budaya. Begitu pula persaingan tenaga kerja yang semakin ketat menjelang pemberlakuan Masyarakat Ekonomi ASEAN (MEA). MEA adalah bentuk integrasi ekonomi regional yang direncanakan pada tahun 2015. Tujuan utama MEA adalah menjadikan ASEAN sebagai pasar tunggal dan basis produksi, yang mana terjadi arus barang, jasa, investigasi dan tenaga terampil yang bebas serta aliran modal yang lebih bebas. MEA akan menjadi kesempatan yang baik bagi Indonesia karena hambatan perdagangan akan cenderung berkurang. Akan tetapi dalam beberapa hal, Indonesia dinilai belum siap menghadapi MEA, hal ini disebabkan daya saing ekonomi social masih rendah (Intra, 2015:3-5).

Mahmud (2016) menyatakan bahwa untuk meningkatkan daya saing ekonomi sosial, Indonesia harus memiliki nilai unggul. Nilai unggul yang harus dimiliki Indonesia membutuhkan Sumber Daya Manusia (SDM) yang handal. Hal ini sangat bergantung pada dunia pendidikan. Pendidikan berperan penting dalam membangun SDM handal yang kompetitif dan mampu bersaing dengan negara lain. Oleh karena itu, untuk menyambut MEA dunia pendidikan Indonesia harus mampu mempersiapkan SDM yang terampil, peka dan kritis dalam menghadapi tantangan serta 
berbagai perubahan yang akan terjadi di dunia pendidikan mendatang. Para siswa saat ini saling berkompetisi untuk mendapatkan prestasi yang terbaik dan selalu ingin menjadi lebih unggul. Guru di sekolah sebagai sosok terdepan di dalam proses pendidikan, dituntut mampu memberikan pengetahuan, sikap, perilaku, dan keterampilan melalui strategi dan pola pembelajaran yang sesuai dengan tuntutan dan perkembangan di abad 21.

Namun, dunia pendidikan di Indonesia masih memiliki beberapa kendala yang berkaitan dengan mutu pendidikan. Terutama dalam mata pelajaran matematika yang diklaim sebagai mata pelajaran yang sulit dan membosankan. Dalam penyelenggaraan TIMSS (Trends in International Mathematics and Science Study) pada tahun 2015, Indonesia berada pada posisi ke 45 dari 50 negara dengan perolehan skor 397 poin. Rerata skor yang diperoleh Indonesia masih di bawah rerata skor internasional (Rahmawati, 2016:2). Dengan ini dapat diketahui bahwa daya saing siswa dalam kemampuan matematika masih tergolong rendah dibanding dengan negara lain. Untuk meningkatkan daya saing siswa terutama dalam bidang matematika, kualitas pendidikan perlu ditingkatkan. Salah satu upaya untuk meningkatkan kualitas Pendidikan adalah adanya pengembangan kurikulum. Sesuai dengan pendapat Mulyasa (2015:64) bahwa kurikulum memiliki peran utama dalam meningkatkan mutu pendidikan. Kurikulum merupakan pedoman dan pegangan tentang jenis, lingkup, dan urutan isi serta proses pendidikan. Kurikulum berfungsi untuk mengarahkan segala aktivitas pendidikan demi tercapainya tujuan pendidikan. Kurikulum harus mampu membekali siswa dengan berbagai kompetensi. Kebijakan penerapan kurikulum di Indonesia dianggap sebagai penentu keberhasilan pendidikan, oleh karena itu Indonesia mengalami beberapa kali pergantian kurikulum pasalnya kurikulum selalu memerlukan pengembangan baru sesuai dengan perkembangan masyarakat.

Kurikulum yang berlaku di Indonesia saat ini adalah Kurikulum 2013. Kurikulum 2013 merupakan kurikulum baru yang dilaksanakan secara bertahap pada satuan pendidikan mulai tahun ajaran 2013/2014 dan baru dilaksanakan secara serentak di seluruh satuan pendidikan pada tahun ajaran 2014/2015. Pada tahun 2016, pemerintah merevisi kurikulum 2013 guna memperbaiki kekurangan dan kelemahan dari kurikulum 2013. Perubahan Kurikulum 2013 edisi revisi tidak membatasi proses berpikir siswa. Teori 5M (mengingat, memahami, menerapkan, menganalisis dan mencipta) tidak hanya sebatas teori saja. Hal ini menuntut keaktifan guru dalam menciptakan dan menumbuhkan berbagai kegiatan sesuai rencana yang telah diprogramkan. Guru memegang peranan penting dalam proses pembelajaran, terutama dalam meningkatkan daya saing siswa.

Peran guru yang paling menonjol dalam implementasi Kurikulum 2013 adalah dalam proses pendekatan saintifik dan penilaian autentik. Pendekatan saintifik bertujuan untuk meningkatkan kemampuan intelek siswa dan penilaian autentik untuk meningkatkan hasil belajar siswa. Menurut Hosnan (2014:36), karakteristik pembelajaran menggunakan pendekatan saintifik adalah sebuah pembelajaran yang berpusat pada siswa (student centered). Siswa dituntut aktif dalam setiap kegiatan inti dalam proses pembelajaran (mengamati, menanya, mengumpulkan informasi, mengolah informasi dan mengomunikasikan). Sedangkan penilaian autentik (Hosnan, 2014:387) adalah pengukuran bermakna secara signifikan atas hasil belajar siswa dalam ranah sikap, pengetahuan dan keterampilan. Penilaian autentik digunakan guru untuk mengumpulkan informasi tentang perkembangan belajar siswa baik intelektual maupun mental siswa. Namun, dalam pelaksanaannya guru masih menghadapi masalah dalam implementasi pendekatan saintifik. Guru juga masih kesulitan membuat instrumen penilaian baik tes maupun non-tes, guru merasa kesulitan dalam mengisi format penilaian terutama rekapitulasi nilai menjadi deskriptif, dan guru belum memahami penilaian autentik.

Tujuan penelitian ini adalah untuk mendeskripsikan implementasi pendekatan saintifik dengan authentic assessment Kurikulum 2013 dalam pembelajaran matematika pada siswa kelas VII MTs Al-Ihsan Krian Tahun Ajaran 2016/2017 dalam kegiatan perencanaan, pelaksanaan dan penilaian pembelajaran. Penelitian ini juga bertujuan untuk mengidentifikasi kendala yang 
ditemukan guru pada tiap kegiatan. Dengan adanya penelitian ini akan membantu guru dalam mengimplementasikan Kurikulum 2013 dengan maksimal.

\section{METODE}

Penelitian ini menggunakan metode kualitatif dengan jenis penelitian deskriptif kualitatif. Peneliti ingin mendeskripsikan implementasi pendekatan saintifik dengan authentic assessment dalam pembelajaran matematika pada siswa kelas VII MTs Al-Ihsan Krian tahun ajaran 2016/2017. Subjek penelitian dalam penelitian ini adalah dua guru kelas VII MTs Al-Ihsan Krian tahun ajaran 2016/2017. Pemilihan subjek penelitian menggunakan criterion based selection yang didasarkan pada asumsi bahwa subjek penelitian yang dipilih sesuai dengan tema penelitian. Sedangkan objek penelitian ini adalah kegiatan-kegiatan yang merupakan bentuk dari implementasi pendekatan saintifik dengan authentic assessment di kelas VII MTs Al-Ihsan Krian.

Instrumen utama dalam penelitian kualitatif adalah peneliti itu sendiri yang disebut dengan human instrument. Sebagai human instrument, peneliti berperan dalam menetapkan fokus penelitian, memilih informan sumber data (subjek penelitian), mengumpulkan data, menganalisis data dan menyimpulkan. Akan tetapi, peneliti juga membutuhkan instrument pendukung sebagai alat pengumpul data. Teknik pengumpulan data dalam penelitian ini, yaitu menggunakan: (1) angket, metode angket yang digunakan dalam penelitian ini adalah angket guru yang digunakan untuk mengumpulkan data dengan cara membuat daftar pertanyaan secara tertulis dan diisi secara tertulis pula. Dalam penelitian ini, angket diberikan kepada guru matematika untuk mengetahui apa saja yang telah dilakukan dan apa yang belum dilakukan guru dalam implementasi pendekatan saintifik dengan authentic assessment Kurikulum 2013. Angket yang digunakan peneliti adalah angket tertutup menggunakan Skala Guttman dengan dua alternatif jawaban ("Ya" dan "Tidak"). Angket tertutup merupakan angket yang didalamnya telah terdapat alternatif jawaban yang telah ditentukan oleh peneliti. (2) observasi, peneliti melakukan kegiatan observasi partisipasi pasif dimana peneliti datang ke tempat kegiatan, namun tidak ikut terlibat di dalamnya. Kegiatan observasi ini bertujuan untuk mengumpulkan data mengenai kegiatan pembelajaran dengan implementasi Kurikulum 2013 serta kendala yang dihadapi guru dan cara mengatasi kendala dalam implementasinya. (3) wawancara adalah percakapan dengan maksud tertentu (Moleong, 2013:186). Percakapan itu dilakukan oleh dua pihak, yaitu pewawancara yang mengajukan pertanyaan dan terwawancara yang memberilan jawaban atas pertanyaan itu. Wawancara dilakukan peneliti untuk menggali informasi lebih mendalam mengenai implementasi pendekatan saintifik dengan authentic assessment dalam pembelajaran matematika pada kelas VII MTs Al-Ihsan Krian beserta kendala yang dihadapi guru dan cara guru mengatasinya. Jenis wawancara yang dilakukan adalah wawancara semiterstruktur. (4) dokumentasi, metode dokumentasi ini digunakan untuk mengumpulkan dokumen yang merupakan catatan peristiwa yang sudah berlalu. Dokumen dimanfaatkan sebagai saksi dari kejadian-kejadian tertentu sebagai bentuk pertanggungjawaban.

Dalam penelitian ini, uji kredibilitas data dilakukan dengan triangulasi. Triangulasi yang digunakan adalah triangulasi sumber. Triangulasi sumber untuk menguji kredibilitas data dengan cara mengecek data yang diperoleh melalui beberapa sumber. Pengecekan keabsahan data dilakukan dengan membandingkan data Subjek 1 dengan data Subjek 2. Setelah data terbukti kredibel, maka data perlu dianalisis untuk mendapatkan kesimpulan yang kredibel.

Peneliti melakukan analisis selama di lapangan dengan melakukan pengumpulan data yang sedang berlangsung dan setelah pengumpulan data sudah mencukupi. Analisis data terdiri dari tiga alur kegiatan yang terjadi secara bersamaan, yaitu reduksi data, penyajian data, dan verifikasi data.

\section{HASIL}

Hasil penelitian mengenai implementasi pendekatan saintifik dengan authentic assessment Kurikulum 2013 dalam pembelajaran matematika pada siswa kelas VII MTs Al-Ihsan Krian ini 
meliputi hasil dari tiga kegiatan, yakni (a) kegiatan perencanaan pembelajaran; (b) kegiatan pelaksanaan pembelajaran; dan (c) kegiatan penilaian pembelajaran. Pada tiap kegiatan tersebut akan dijelaskan mengenai paparan data hasil penelitian, pengecekan keabsahan data dan analisis data.

a. Kegiatan Perencanaan Pembelajaran

Sebelum pelaksanaan pembelajaran, guru harus mempunyai rencana mengenai langkahlangkah yang harus dilakukan dalam kegiatan pembelajaran. Guru harus membuat Rencana Pelaksanaan Pembelajaran (RPP) yang digunakan sebagai pedoman pelaksanaan pembelajaran di dalam kelas. Hal ini untuk mengetahui kesiapan guru dalam proses belajar mengajar. Data perencanaan pembelajaran ini diperoleh dari hasil studi dokumentasi terhadap RPP yang disusun oleh guru. Selain itu, data diperoleh dari hasil wawancara terhadap subjek penelitian. Berikut adalah data perencanaan implementasi pendekatan saintifik dengan authentic assessment.

(1) Data Kegiatan Perencanaan Subjek 1

Subjek 1 membuat RPP yang digunakan sebagai pedoman dalam kegiatan pelaksanaan pembelajaran. Berdasarkan hasil studi dokumentasi, komponen RPP yang disusun oleh Subjek 1 meliputi identitas sekolah, mata pelajaran, kelas/semester, alokasi waktu, Kompetensi Inti, Kompetensi Dasar, Indikator pencapaian kompetensi, tujuan pembelajaran, materi pembelajaran, pendekatan dan metode pembelajaran, media pembelajaran, sumber belajar, langkah-langkah pembelajaran dan penilaian. Subjek 1 menjabarkan setiap langkah-langkah pembelajaran dengan sintak pendekatan saintifik dan juga mencantumkan teknik penilaian dengan authentic assessment. Di dalam RPP juga dicantumkan instrumen penilaian yang digunakan untuk menilai pengetahuan, sikap dan keterampilan siswa. Kendala yang dihadapi Subjek 1 berupa kesulitan dalam mengembangkan kegiatan pembelajaran. Untuk itu, Subjek 1 mengatasinya dengan browsing di internet mengenai kegiatan pembelajaran yang menyenangkan.

(2) Data Kegiatan Perencanaan Subjek 2

Berdasarkan hasil studi dokumentasi, komponen RPP yang disusun oleh Subjek 2 meliputi identitas sekolah, mata pelajaran, kelas/semester, alokasi waktu, Kompetensi Inti, Kompetensi Dasar, Indikator pencapaian kompetensi, tujuan pembelajaran, materi pembelajaran, pendekatan dan metode pembelajaran, media pembelajaran, sumber belajar, langkah-langkah pembelajaran dan penilaian. Subjek 2 menjabarkan setiap langkahlangkah pembelajaran dengan sintak pendekatan saintifik dan juga mencantumkan teknik penilaian dengan authentic assessment. Subjek 2 juga mencantumkan instrumen penilaian yang digunakan untuk menilai pengetahuan, sikap dan keterampilan siswa. Kendala yang dihadapi Subjek 2 berupa kesulitan dalam mengembangkan kegiatan pembelajaran. Untuk itu, Subjek 2 berdiskusi dengan sesama guru matematika yang lain untuk mengetahui model pembelajaran yang sesuai dengan materi pelajaran.

b. Kegiatan Pelaksanaan Pembelajaran

Pelaksanaan pembelajaran merupakan bentuk realisasi dari RPP yang telah direncanakan. Data pelaksanaan pembelajaran ini diperoleh dari pengisian angket, observasi kelas, dan kegiatan wawancara. Berikut adalah data pelaksanaan pembelajaran implementasi pendekatan saintifik dengan authentic assessment Kurikulum 2013.

(1) Data Kegiatan Pelaksanaan Subjek 1

Subjek 1 telah melaksanakan kegiatan pembelajaran sesuai dengan RPP yang disusun meliputi kegiatan pendahuluan, kegiatan inti dan kegiatan penutup. Dalam kegiatan pendahuluan, yang dilakukan Subjek 1 adalah mengkondisikan siswa, mengucapkan salam, mengecek kehadiran siswa, menyampaikan kompetensi yang akan dicapai serta menyampaikan teknik penilaian yang akan digunakan dalam proses pembelajaran. Subjek 1 melaksanakan pembelajaran dengan implementasi pendekatan saintifik pada kegiatan inti 
yang meliputi kegiatan 5M (mengamati, menanya, mengumpulkan informasi/mencoba, mengolah informasi/menalar dan mengkomunikasikan). Subjek 1 melakasanakan kegiatan penutup yang meliputi kegiatan membuat rangkuman dari apa yang telah dipelajari bersama siswa, memberikan umpan balik bersama siswa terhadap proses dan hasil pembelajaran, melakukan tindak lanjut dalam bentuk pemberian tugas proyek berkelompok, melakukan penilaian dan menyampaikan rencana pembelajaran pada pertemuan selanjutnya.

Kendala yang ditemukan Subjek 1 dalam kegiatan pelaksanaan pembelajaran adalah tidak adanya buku paket siswa yang membuat siswa kurang kondusif sehingga Subjek 1 membuat LKS sebagai panduan belajar siswa yang berisi materi yang diajarkan. Selain itu, sarana dan prasarana yang kurang memadai sehingga Subjek 1 hanya memanfaatkan sarana dan prasarana yang tersedia dengan sebaik-baiknya.

(2) Data Kegiatan Pelaksanaan Subjek 2

Subjek 2 telah melaksanakan kegiatan pembelajaran sesuai dengan RPP yang disusun meliputi kegiatan pendahuluan, kegiatan inti dan kegiatan penutup. Dalam kegiatan pendahuluan, yang dilakukan Subjek 2 adalah mengkondisikan siswa, mengucapkan salam, mengecek kehadiran siswa, menyampaikan kompetensi yang akan dicapai serta menyampaikan teknik penilaian yang akan digunakan dalam proses pembelajaran. Subjek 2 melaksanakan pembelajaran dengan implementasi pendekatan saintifik pada kegiatan inti yang meliputi kegiatan 5M (mengamati, menanya, mengumpulkan informasi/mencoba, mengolah informasi/menalar dan mengkomunikasikan). Subjek 2 melakasanakan kegiatan penutup yang meliputi kegiatan membuat rangkuman dari apa yang telah dipelajari bersama siswa, memberikan umpan balik bersama siswa terhadap proses dan hasil pembelajaran, melakukan tindak lanjut dalam bentuk pemberian tugas proyek berkelompok, melakukan penilaian dan menyampaikan rencana pembelajaran pada pertemuan selanjutnya.

Kendala yang ditemukan Subjek 2 dalam kegiatan pelaksanaan pembelajaran adalah tidak adanya buku paket siswa merasa kesulitan dalam belajar sehingga Subjek 2 membuat LKS langkah-langkah pembelajaran dengan sintak pendekatan saintifik. Selain itu, sarana dan prasarana yang kurang memadai sehingga Subjek 2 hanya memanfaatkan sarana dan prasarana yang tersedia dengan sebaik-baiknya.

c. Kegiatan Penilaian Pembelajaran

Data kegiatan penilaian pembelajaran diperoleh dari hasil pengisian angket, observasi kelas, kegiatan wawancara dan studi dokumentasi.

(1) Data Kegiatan Penilaian Subjek 1

Subjek 1 melakukan semua kegiatan dalam penilaian authentic assessment yang meliputi penilaian sikap, penilaian pengetahuan dan penilaian keterampilan. Subjek 1 selalu menggunakan pedoman penskoran dalam kegiatan penilaian. Sebelum melakukan penilaian, Subjek 1 menentukan KKM yang harus dicapai siswa. Subjek 1 selalu menggunakan pedoman penskoran dalam kegiatan penilaian. Subjek 1 menilai sikap siswa dengan pengamatan/observasi. Subjek 1 menilai pengetahuan siswa dari tes tulis dan penugasan baik individu maupun kelompok. Subjek 1 menilai keterampilan siswa dari proses mengerjakan tugas dalam kelompok dan penugasan proyek. selain itu, Subjek 1 juga melakukan penilaian portofolio. Kendala yang ditemukan Subjek 1 dalam kegiatan penilaian adalah authentic assessment terlalu rumit sehingga Subjek 1 harus belajar terus mengenai authentic assessment dengan mengikuti workshop mengenai authentic assessment.

(2) Data Kegiatan Penilaian Subjek 2

Subjek 2 melakukan semua kegiatan dalam penilaian authentic assessment yang meliputi penilaian sikap, penilaian pengetahuan dan penilaian keterampilan. Subjek 2 selalu 
menggunakan pedoman penskoran dalam kegiatan penilaian. Sebelum melakukan penilaian, Subjek 2 menentukan KKM yang harus dicapai siswa. Subjek 2 selalu menggunakan pedoman penskoran dalam kegiatan penilaian. Subjek 2 menilai sikap siswa dengan pengamatan/observasi. Subjek 2 menilai pengetahuan siswa dari tes tulis dan penugasan baik individu maupun kelompok. Subjek 2 menilai keterampilan siswa dari proses mengerjakan tugas dalam kelompok dan penugasan proyek. selain itu, Subjek 2 juga melakukan penilaian portofolio. Kendala yang ditemukan Subjek 2 dalam kegiatan penilaian adalah terlalu banyak aspek yang dinilai sehingga Subjek 2 harus segera merekap nilai agar tidak menumpuk.

\section{PEMBAHASAN}

Penelitian ini menggunakan pendekatan kualitatif dengan jenis penelitian deskriptif kualitatif dikarenakan peneliti ingin mendeskripsikan implementasi pendekatan saintifik dengan authentic assessment Kurikulum 2013 dalam pembelajaran matematika pada siswa kelas VII MTs Al-Ihsan Krian tahun ajaran 2016/2017. Menurut Undang-Undang Sistem Pendidikan Indonesia Nomor 20 Tahun 2003 pasal 1 (dalam Kusbudiyah, 2014) menyatakan bahwa kurikulum adalah seperangkat rencana dan pengaturan mengenai tujuan, isi dan bahan pelajaran serta cara yang digunakan sebagai pedoman penyelenggaraan kegiatan pembelajaran untuk mencapai tujuan pendidikan bermutu.

Data dalam penelitian ini diperoleh dari hasil pengisian angket guru, observasi, wawancara dan studi dokumentasi. Kemudian untuk mengecek keabsahan data, peneliti melakukan teknik triangulasi sumber dengan membandingkan data dari Subjek 1 dan Subjek 2. Kemudian data tersebut dianalisis untuk memperoleh kesimpulan yang absah.

Dalam Lampiran Permendikbud Nomor 22 Tahun 2016 tentang Standar Proses Pendidikan Dasar dan Pendidikan Menengah (2016:2) dinyatakan bahwa strandar proses mencakup perencanaan proses pembelajaran, pelaksanaan proses pembelajaran, dan penilaian hasil pembelajaran. Berdasarkan hasil penelitian, diperoleh data mengenai implementasi pendekatan saintifik dengan authentic assessment Kurikulum 2013 dalam pembelajaran matematika pada siswa kelas VII MTs Al-Ihsan Krian tahun ajaran 2016/2017 yang meliputi kegiatan perencanaan, pelaksanaan dan penilaian. Data kegiatan perencanaan diperoleh peneliti dari studi kasus terhadap RPP yang digunakan guru sebagai pedoman kegiatan pembelajaran. Data pelaksanaan pembelajaran dan data penilaian pembelajaran diperoleh dari pemberian angket yang telah divalidasi oleh validator. Peneliti mengidentifikasi apa saja yang telah dilakukan guru dalam implementasi pendekatan saintifik dengan authentic assessment dalam pembelajaran matematika. Setelah itu, peneliti melakukan kegiatan observasi di kelas untuk mengecek kegiatan yang dilakukan guru dalam pembelajaran sesuai dengan keadaan sebenarnya. Kemudian dilakukan wawancara semiterstruktur kepada guru untuk mengetahui kendala yang ditemukan guru dalam proses pembelajaran baik pada pelaksanaannya atau penilaian. Stelah data terkumpul, dilakukan pengecekan keabsahan data dengan membandingkan data Subjek 1 dan data Subjek 2. Ternyata, data tersebut sama dan data tersebut dianggap absah.

\section{SIMPULAN DAN SARAN}

Berdasarkan hasil penelitian ini disimpulkan bahwa guru matematika kelas VII MTs Al-Isan Krian telah merencanakan kegiatan pembelajaran sebelum melaksanakan pembelajaran. Guru menyusun RPP dengan mengkaji silabus dan menggunakan buku guru sebagai acuan. Guru telah melaksanakan pembelajaran dengan sintak pendekatan saintifik melalui kegiatan 5M yakni mengamati, menanya, mengumpulkan informasi/mencoba, mengolah informasi/menalar, dan mengkomunikasikan. Namun kegiatan 5M tersebut kurang maksimal dikarenakan tidak adanya buku paket siswa serta sarana dan prasarana kurang memadai. Guru telah menggunakan authentic assessment dalam kegiatan penilaian, yakni dengan penilaian sikap, pengetahuan dan keterampilan. 
Akan tetapi guru merasa terlalu banyak aspek yang dinilai sehingga guru harus segera merekap nilai.

Dalam implementasi kurikulum 2013 dalam pembelajaran matematika, hendaknya guru terus belajar dan selalu beradaptasi mengenai pengembangan Kurikulum 2013 terutama pada implementasinya menggunakan pendekatan saintifik dan authentic assessment. Untuk peneliti selanjutnya, hendaknya mengkaji lebih dalam mengenai implementasi pendekatan saintifik dan authentic assessment dengan memperbanyak subjek penelitian dari tingkat kelas yang bervariasi supaya hasil penelitian dapat maksimal.

\section{DAFTAR RUJUKAN}

As'ari, Abdur Rahman. 2014. Prespektif Global tentang Kurikulum 2013 secara Umum, dan Pembelajaran Matematika secara Khusus. Materi disajikan dalam Whorkshop mengenai Pembelajaran Matematika Berbasis Kurikulum 2013, Program Studi Pendidikan Matematika Universitas Islam Malang, Malang, 09 Juni 2014.

Hosnan. 2014. Pendekatan Saintifik dan Kontekstual dalam Pembelajaran Abad 21 Kunci Sukses Implementasi Kurikulum 2013. Bogor: Ghalia Indonesia

Intra. 2015. Welcome MEA (Masyarakat Ekonomi Asean), hlm. 3-5. Edisi VIII.

Kunandar. 2015. Penilaian Autentik (Penilaian Hasil Belajar Peserta Didik Berdasarkan Kurikulum 2013). Jakarta: PT RajaGafindo Persada.

Kusbudiyah, Yayah. 2014. Kajian Materi Kediklatan tentang Perubahan Kurikulum secara Teoritis. (Online), (http://bdkbandung.kemenag.go.id diakses tanggal 25 Desember 2016).

Mahmud, Amirudin. 2016. MEA dan Pendidikan Kita. (Online), (http://kompasiana.com), diakses pada tanggal 22 Desember 2016.

Moleong, Lexy J. 2013. Metodologi Penelitian Kualitatif. Bandung: PT Remaja Rosdakarya.

Mulyasa, E. 2015. Pengembangan dan Implementasi Kurikulum 2013. Bandung: PT Remaja Rosdakarya.

Rahmawati. 2016. Seminar Hasil TIMSS Tahun 2015. (Online), (www.timss2015.org), diakses pada tanggal 04 Juni 2017. 